\title{
An investigation of mercury distribution in the soils around gold mining area at Dar-Mali locality, river Nile State, Sudan

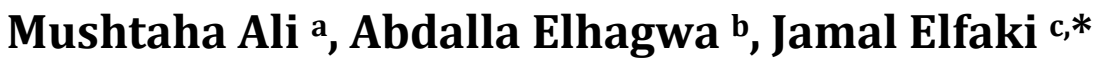

\author{
a General Administration of Natural Resource and Sustainable Development, Khartoum, Sudan \\ b Agricultural Research Corporation (ARC), Land and Water Research Centre, Wad Madani, Sudan \\ c Faculty of Agriculture, Nile Valley University, River Nile State, Sudan
}

\section{Article Info}

Received : 14.12 .2017

Accepted : 30.09.2018

\begin{abstract}
An artisanal gold mining region located in North of Atbara (Dar-Mali locality), River Nile State, Sudan (17.82289 to $17.82389 \mathrm{~N}$ and 33.99974 to $34.02127 \mathrm{E}$ ) has been studied with the aim to evaluate the soil contamination with mercury (Hg) using two parameters; (i) Comparison of the $\mathrm{Hg}$ concentration with the mean concentrations in world soils, (ii) Enrichment Factor (EF). The results revealed that, the concentrations of the $\mathrm{Hg}$ are varying in the studied area and the highest concentrations were obtained inside the mining basins used for gold extraction $\left(2.62 \mathrm{mg} \mathrm{kg}^{-1}\right.$ soil) it is around 29 times more than mean $\mathrm{Hg}$ concentration in world soils, while the lower concentrations are found at recent Nile River terrace $\left(0.10 \mathrm{mg} \mathrm{kg}^{-1}\right.$ soil $)$. The results also indicated that the soil samples collected from inside mining basins had a highest E.F value (352.84) that means, this site must be closed and remediation process should be started immediately. While the E.F value of recent Nile River terrace site was 8.74, means, all studied sites have significant contamination with $\mathrm{Hg}$. The mobility of $\mathrm{Hg}$ may have influenced by northeast wind, or water runoff from mining zone to nearest areas at same wind direction or water flow direction.
\end{abstract}

Keywords: Sudan, River Nile State, Hg concentration, gold mining, enrichment factor, mining basins.

(C) 2018 Federation of Eurasian Soil Science Societies. All rights reserved

\section{Introduction}

Soil is not only a medium for plants growth or waste disposal but also a transmitter of many pollutants to surface water, ground water, atmosphere and food. Soil pollution may threaten human health not only through its effect on hygiene quality of food and drinking water, but also through its effect on air quality (Wong, 1996).

Informal gold mining constitutes an important source of income for many people in Africa, Southeast Asia and China. this growing industry employs more than 10 million people around the world, and there is a generalized environmental menace to human health because most of the gold is extracted by $\mathrm{Hg}$ amalgamation, leading to $\mathrm{Hg}$ contamination of the ecosystems by releasing more than 650.000 tons of $\mathrm{Hg}$ annually (Olivero and Solano, 1998; Guedron et al., 2009).

Mining has been identified as one of human activities, which can have a negative impact on the environment quality (Donkor et al., 2005). It causes the destruction of natural ecosystems through removal of soil and vegetation and burial beneath waste disposal sites funeral (Cooke and Johnson, 2002). Mining waste can be divided into two categories: (i) mine tailings, generated during processing of the ore, and (ii) waste rock produced when uncovering the ore body (Ledin and Pederse, 1996).

\footnotetext{
${ }^{*}$ Corresponding author.

Faculty of Agriculture, Nile Valley University, River Nile State, Sudan

Tel.: +249912387452

e-ISSN: 2147-4249
} 
Mercury $(\mathrm{Hg})$ is consider an important pollutant due to its global distribution, bioaccumulation and toxicity (Yin et al., 2014), soils can accumulate up to 75\% of the Hg present in the biosphere (Mason and Sheu, 2002), mostly as a result of the affinity of $\mathrm{Hg}$ for soil organic matter and $\mathrm{Al}$ and Fe (Schuster, 1991; Skyllberg et al., 2006). Hg is a very toxic and insignificant element of life. Nevertheless, elemental $\mathrm{Hg}$ and its compounds are highly volatile and can easily migrate to environments that enter the food chain, which can cause irreversible damage to people and animal life, the risk for mercury exposure is significant, elemental mercury exposure can be toxic to multiple organ systems, including the nervous and dermatologic systems (Fernandes et al., 2012).

The Hg is widely used for the gold extraction in our study area, so, a high concentration of it are expected will be found in the mining zone and other adjacent areas at same wind direction or water flow direction in the study area. The main objectives of this study were to assessing the distribution of $\mathrm{Hg}$ in soils around gold mining area with the hypothesis that it could be leaching from tailings and deposition at mining area to nearest locations at Dar-Mali locality, River Nile State, Sudan, this study also aim to investigate the effect of vicinity and distance from mining zone on concentration of $\mathrm{Hg}$ in the study area.

\section{Material and Methods}

The investigated area is located at North of Atbara city, River Nile State, Sudan, with an altitude of (336-358 meters) above sea level. The studied area covered around $10.0 \mathrm{~km}^{2}$ and it is located within coordinates of 17.82289 to $17.82389 \mathrm{~N}$ and 33.99974 to $34.02127 \mathrm{E}$ Fig1 The study area falls within the arid climatic zone. The average annual rainfall varies from 0 to $100 \mathrm{~mm}$. the mean maximum temperature of the hottest months (May and June) is $43^{\circ} \mathrm{C}$. The mean minimum temperature of the coldest month (January) was less than $13^{\circ} \mathrm{C}$. The mean annual relative humidity ranges between 15 to 21\% (January to February), and less than 15\% (March to June). The predominant natural vegetation consists of the following species; Tundub (Capparis decidua), Seyal (Acacia tortilis), Usher, Musket (Prosopischilensis), Heglig (Balanitesaegypiaca) and Seder (Zizyphusspina-christi). The calculated soil temperature regime is hyperthermic and soil moisture regime is aridic (Elfaki et al., 2015). The soils of the study area belong within Entisols and Aridisols orders (USDA, 2014a).

Twenty soil samples were collected from different sites around gold mining area at Dar-Mali locality, (Table 1). At each site, approximately $5 \mathrm{~kg}$ of soil sample was collected from the depth of $0-30 \mathrm{~cm}$ using an auger and kept in a cloth bag. Each sample was labeled with; collected data, site coordinates, sample number, then, subjected to physical and chemical analyses at the soil laboratories.

Table 1. Geographical coordinates, elevation, and texture class of the study sites

\begin{tabular}{|c|c|c|c|c|c|}
\hline \multirow[t]{2}{*}{ No } & \multirow[t]{2}{*}{ Descriptive Locations } & \multicolumn{2}{|c|}{ Geographical coordinates } & \multirow{2}{*}{$\begin{array}{c}\text { Elevation } \\
\text { (m ASL) }\end{array}$} & \multirow{2}{*}{$\begin{array}{l}\text { Texture } \\
\text { Class }\end{array}$} \\
\hline & & $\mathrm{N}$ & $\mathrm{E}$ & & \\
\hline 1 & Instructional farm (Nile Valley University) & 17.82289 & 34.02127 & 356 & Silt loam \\
\hline 2 & Instructional farm, Nile Valley University & 17.82283 & 34.02044 & 354 & Silt loam \\
\hline 3 & Instructional farm, Nile Valley University & 17.82062 & 34.0203 & 351 & Silt loam \\
\hline 4 & Instructional farm, Nile Valley University & 17.82044 & 34.02142 & 353 & Silt loam \\
\hline 5 & Near wells of the instructional farm & 17.82214 & 34.02237 & 358 & Loamy sand \\
\hline 6 & Farm near mining mills & 17.82503 & 34.01473 & 354 & Loamy sand \\
\hline 7 & Outside the farm in the mining zone & 17.82503 & 34.01473 & 354 & Sandy Loam \\
\hline 8 & Outside the mills in mining zone & 17.82578 & 34.01468 & 356 & Sand \\
\hline 9 & Outside washing basin and the gold extraction & 17.82288 & 34.01498 & 352 & Sandy Loam \\
\hline 10 & Outside washing basin and the gold extraction & 17.82288 & 34.01498 & 352 & Loamy sand \\
\hline 11 & Outside washing basin (red color) & 17.82145 & 34.01407 & 351 & Sandy Loam \\
\hline 12 & Inside washing basin (red color) & 17.82145 & 34.01407 & 351 & Loamy sand \\
\hline 13 & Middle of mining zone & 17.82167 & 34.01612 & 357 & Sandy Loam \\
\hline 14 & Farm near mining zone & 17.82483 & 34.00957 & 351 & Sandy Loam \\
\hline 15 & Recent Nile River terrace & 17.81779 & 33.99229 & 349 & Sandy Loam \\
\hline 16 & Recent Nile River terrace & 17.81779 & 33.99229 & 349 & Silt loam \\
\hline 17 & Inside Residential zone & 17.81763 & 33.99478 & 351 & Sandy Loam \\
\hline 18 & Inside Residential zone & 17.82344 & 33.99523 & 352 & Sandy Loam \\
\hline 19 & Inside Agric. College (Nile Valley Uni.) & 17.82389 & 33.99974 & 356 & Sand \\
\hline 20 & Inside Agric. College (Nile Valley Uni.) & 17.82389 & 33.99974 & 356 & Sand \\
\hline
\end{tabular}

In order to calculate to the distances between mining zone and other studied areas which may affected by $\mathrm{Hg}$ pollution which used in mining zone for extraction of gold, Sinnott, (1984) equation Eq. (1) was used to 
convert the longitudes and latitudes coordination to distances. Then, the Sigma plot v12 software was used to draw the distribution of $\mathrm{Hg}$ concentration to all studied areas.

$$
\Delta \widehat{\sigma}=2 \arcsin \left(\sqrt{\sin ^{2}\left(\frac{\Delta \phi}{2}\right)+\cos \phi_{s} \cos \phi_{f} \sin ^{2}\left(\frac{\Delta \lambda}{2}\right)}\right)
$$

$\begin{array}{cll}\Delta \sigma & \text { Interior Spherical Angle } \\ \Delta \phi & \text { Latitude1 - Latitude2 } \\ \phi_{\mathrm{s}} & \text { Latitude1 } \\ \phi_{\mathrm{f}} & \text { Latitude2 } \\ \Delta \lambda & \text { Longitude1 - Longitude2 }\end{array}$

Eq. (1) Sinnott, (1984) equation used to calculate the distance between two points.

\section{Enrichment factor (EF)}

The enrichment factor (EF) was calculated using Dragovic et al. (2008) formula

$$
E F=\left(\left(\frac{C_{x}}{C_{F e}}\right) \text { sediment }\right) /\left(\left(\frac{C_{x}}{C_{F e}}\right) \text { Earth'scrust }\right)^{\prime}
$$

Eq. (2) Dragovic et al. (2008) Enrichment factor formula

Where;

$\left(\mathrm{C}_{\mathrm{x}} / \mathrm{C}_{\mathrm{Fe}}\right)$ sediment $=$ the concentration of an element / the concentration of Fe in the sample $\left(\mathrm{C}_{\mathrm{x}} / \mathrm{C}_{\mathrm{Fe}}\right)$ earth's crust = concentration of a metal in the earth crust /the concentration of Fe in the earth crust.

Dragovic et al. (2008) classified the EF in to classes as the following scale; EF (2-5) is moderate contamination, EF (5-20) means significant contamination, EF (20-40) high contamination and EF (>40) classified as very high contamination.

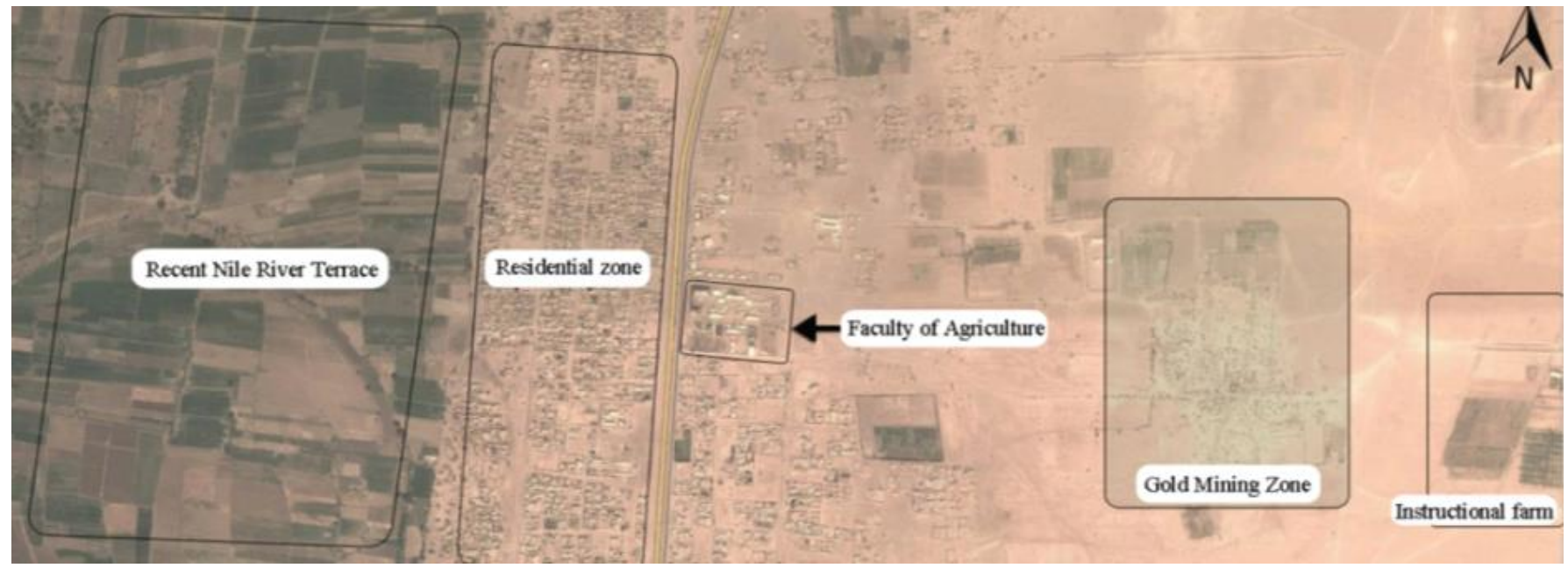

Figure 1. Google map image of study area

\section{Determination of soil properties}

In the laboratory, soil samples were air-dried $\left(25 \pm 2^{\circ} \mathrm{C}\right)$ and passed through $2 \mathrm{~mm}$ mesh sieve to obtain the fine earth fraction. The particles-size distribution of the soil samples was determined using pipette method which was recommended by Elfaki et al. (2016b), and the textural class was obtained by using the USDA textural triangle according to (USDA, 2014b). Soil pH was measured in 1:5 soil suspensions using a digital pH meter Jenway Model 3510, The electrical conductivity (EC dS/m at $25^{\circ} \mathrm{C}$ ) was determined in 1:5 soil extract using a conductivity meter Jenway (Model 4510), Calcium carbonate percent was estimated by Calcimeter which recommend by Elfaki et al. (2016a).

\section{Determination of $\mathrm{Hg}$ in the soil samples}

Microwave digestion oven model (CEM Mars 5) was used to digest soil samples, 1gram of air-dried soil was used after a well-milling, and then placed in a microwave oven pipes. A $10 \mathrm{ml}$ aliquot of nitric acid was added to each pipe containing soil sample and well closed, then placed into the microwave oven, and digested using (EPA-3051A) method described by (Link et al., 1997). After samples digestion, extracted samples were transferred quantitatively into $100 \mathrm{ml}$ volumetric flask and the volume was completed by deionized water to the mark. All digested samples were filtered using filter paper (Whatman No. 42) and then transferred to 
(Perkin Elmer 350D ICP mass spectrometer) after standard curve was prepared from different concentrations (1 ppb, 5 ppb, 10 ppb, 25 ppb, 50 ppb, 100 ppb) of $\mathrm{Hg}$ in order to achieve accurate results of Hg concentration at ppb levels.

\section{Results and Discussion}

\section{General characteristics and topography of the study area}

Highest elevation in the study area was recorded at the instructional farm for Agricultural College (358m ASL) and lowest elevation recorded at recent Nile River terrace (349m ASL), which means the study area was completely slopes towards the River Nile. That may increase the risk of pollutants to transfer from mining zone towards the River Nile (especially at raining season) or via wind through transition and sedimentation processes. The descriptive and geographical locations, textural classes, calcium carbonate percentage of all sites were presented in (Table 2). The soil texture ranged from sandy loam at the recent terrace, silt loam at the second instructional farm - Nile Valley University (NVU).

Table 2. Some soil physico-chemical properties of the study area

\begin{tabular}{|c|c|c|c|c|c|c|c|c|}
\hline Site & Rate & $\mathrm{pH}$ & $\begin{array}{c}\mathrm{EC} \\
\mathrm{dS} \mathrm{m}^{-1}\end{array}$ & $\begin{array}{c}\mathrm{CaCO}_{3}, \\
\%\end{array}$ & $\begin{array}{l}\text { Sand, } \\
\% \\
\end{array}$ & $\begin{array}{l}\text { Silt, } \\
\%\end{array}$ & $\begin{array}{c}\text { Clay, } \\
\% \\
\end{array}$ & $\begin{array}{r}\text { Dominant } \\
\text { Textural Class } \\
\end{array}$ \\
\hline \multirow{3}{*}{$\begin{array}{l}\text { Instructional farm } \\
\text { (NVU) }\end{array}$} & Max & 8.73 & 4.57 & 7.4 & 52.57 & 61.14 & 6.66 & \multirow{3}{*}{ Silt loam } \\
\hline & Min & 7.86 & 0.15 & 2.75 & 32.61 & 41.57 & 5.49 & \\
\hline & Average & 8.26 & 1.06 & 4.78 & 39.44 & 54.61 & 5.95 & \\
\hline \multirow{3}{*}{$\begin{array}{l}\text { Faculty of Agriculture } \\
\text { (NVU) }\end{array}$} & Max & 8.80 & 0.57 & 3.44 & 87.99 & 12.13 & 1.75 & \multirow{3}{*}{ Sand } \\
\hline & Min & 8.35 & 0.46 & 2.58 & 86.12 & 11.78 & 0.23 & \\
\hline & Average & 8.58 & 0.51 & 3.01 & 87.06 & 11.96 & 0.99 & \\
\hline \multirow{3}{*}{$\begin{array}{l}\text { Inside Residential } \\
\text { area }\end{array}$} & Max & 8.80 & 4.64 & 4.64 & 58.07 & 37.78 & 12.00 & \multirow{3}{*}{ Sandy loam } \\
\hline & Min & 8.15 & 2.58 & 2.58 & 56.00 & 32.0 & 4.16 & \\
\hline & Average & 8.48 & 3.61 & 3.61 & 57.04 & 34.89 & 8.08 & \\
\hline \multirow[t]{3}{*}{ Mining area } & Max & 8.68 & 0.19 & 10.32 & 86.79 & 49.96 & 64.33 & \multirow{3}{*}{ Sandy loam } \\
\hline & Min & 8.19 & 0.09 & 3.44 & 7.32 & 13.24 & 5.74 & \\
\hline & Average & 8.48 & 0.13 & 5.59 & 52.38 & 30.87 & 20.95 & \\
\hline \multirow{3}{*}{$\begin{array}{l}\text { Recent Nile River } \\
\text { terrace }\end{array}$} & Max & 8.42 & 0.25 & 5.5 & 48.38 & 62.98 & 31.41 & \multirow{3}{*}{ Silt loam } \\
\hline & Min & 8.01 & 0.23 & 4.47 & 5.61 & 47.77 & 3.85 & \\
\hline & Average & 8.22 & 0.24 & 4.98 & 26.99 & 55.38 & 17.63 & \\
\hline \multirow{3}{*}{$\begin{array}{l}\text { Outside gold extraction } \\
\text { basins }\end{array}$} & Max & 8.76 & 20.9 & 6.02 & 77.8 & 37.21 & 9.85 & \multirow{3}{*}{ Sandy loam } \\
\hline & Min & 7.46 & 0.14 & 2.58 & 57.21 & 20.53 & 1.66 & \\
\hline & Average & 8.15 & 7.43 & 4.3 & 62.65 & 31.55 & 5.80 & \\
\hline \multirow{3}{*}{$\begin{array}{l}\text { Inside gold extraction } \\
\text { basins }\end{array}$} & Max & 8.11 & 0.41 & ND & 81.48 & 20.53 & 1.66 & \multirow{3}{*}{ Loamy sand } \\
\hline & Min & - & - & ND & 77.8 & 18.28 & 0.24 & \\
\hline & Average & - & - & ND & 79.6 & 19.41 & 0.95 & \\
\hline
\end{tabular}

\section{Soil properties of study area}

Table 2 shows the soil physio-chemical properties, the soil reaction at the study area was varied from alkaline to strongly alkaline according to Marx and Stevens (1999), with a pH values ranged from 7.46 to 8.8. The composite sample taken from outside washing basin showed least value of soil reaction (pH 7.46). This could be due to the washing of soil bases through mining process and their later removal during gold extraction. The EC values ranged from 0.13 to $20.9 \mathrm{dS} \mathrm{m}^{-1}$, suggesting non-saline to extremely saline conditions at different sites according to Rhoades (1996). The content of the calcium carbonate $\left(\% \mathrm{CaCO}_{3}\right)$ was varied in all sites from non-calcareous to moderately calcareous according to FAO (2006) guidelines, while $\mathrm{CaCO}_{3}$ was disappeared inside gold extraction basin (Figure 2), this could be due to possibility of dissolution and transportation of $\mathrm{CaCO}_{3}$ inside soil depths via washing water. the dominant texture of the studied sites was sand fraction (up to $87.99 \%$ ).

\section{Mobility and distribution of $\mathrm{Hg}$ in soils of the study area:}

According to table3, which present the maximum, minimum, and mean of $\mathrm{Hg}$ concentrations ( $\mathrm{mg} \mathrm{kg}^{-1} \mathrm{soil}_{\text {) }}$ in the soils of the study area. The highest concentrations were obtained at the mining zone particularly inside gold extraction basins ( $2.62 \mathrm{mg} \mathrm{kg}^{-1}$ soil), and the minimum concentrations were found at recent Nile River terrace $\left(0.10 \mathrm{mg} \mathrm{kg}^{-1}\right.$ soil). Generally, the $\mathrm{Hg}$ concentration in the study area were rated as to following sequences; Inside gold extraction basin s> Outside gold extraction basins > around gold mining zone > Instructional farm (Nile Valley University) > Inside residential zone> Agricultural college (Nile Valley University) > Recent Nile River terrace. 


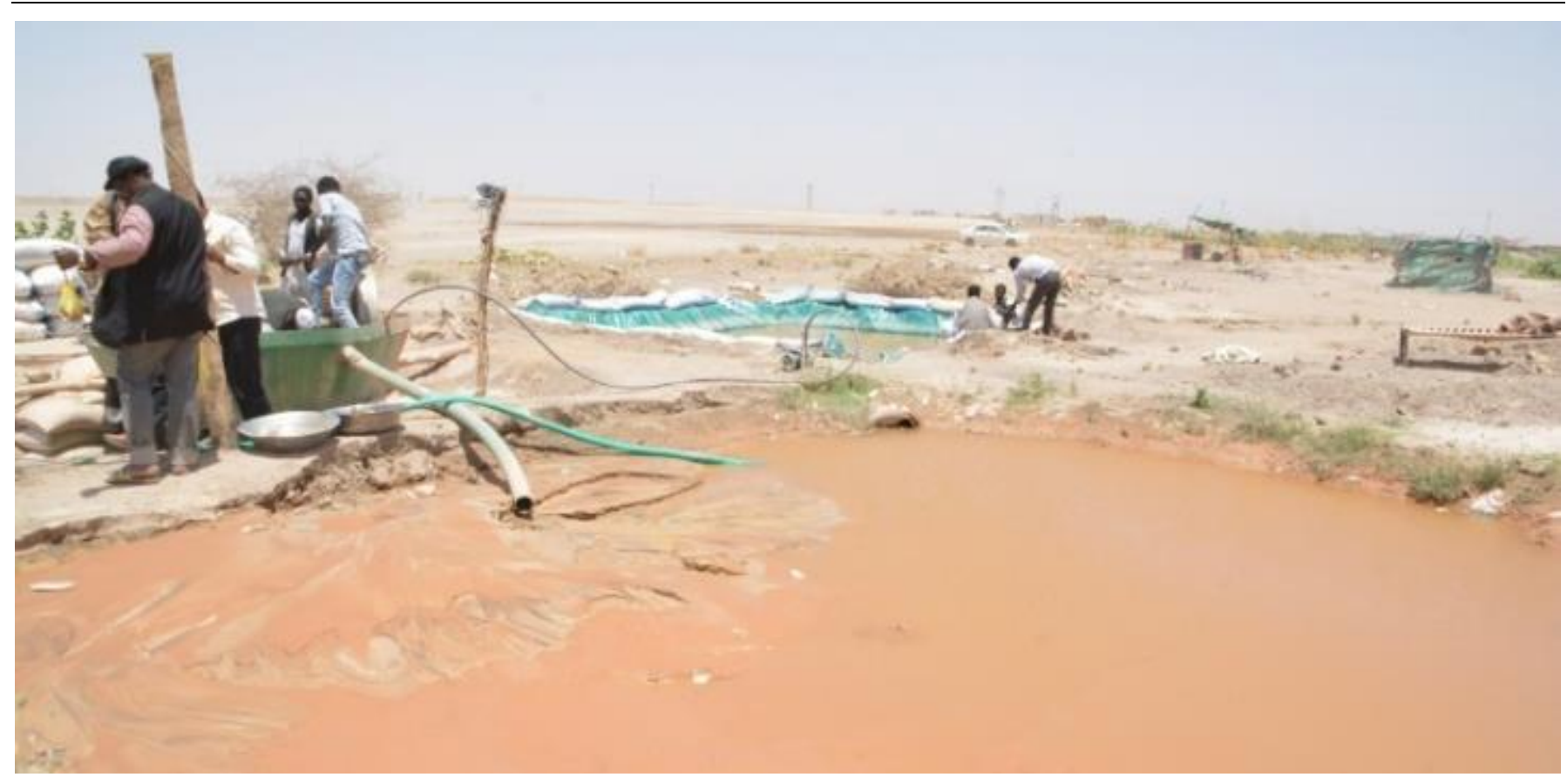

Figure 2. Gold extraction basin

Table 3. Maximum, minimum and mean concentrations of Hg in the study area

\begin{tabular}{|c|c|c|}
\hline Sites & & ations (mg kg-1 soil) \\
\hline \multirow{3}{*}{ Instructional farm (Nile Valley University) } & Max & 0.10 \\
\hline & Min & 0.21 \\
\hline & Mean & 0.16 \\
\hline \multirow{3}{*}{ Agricultural College (Nile Valley University) } & Max & 0.31 \\
\hline & Min & 0.26 \\
\hline & Mean & 0.29 \\
\hline \multirow{3}{*}{ Inside Residential zone } & Max & 0.65 \\
\hline & Min & 0.13 \\
\hline & Mean & 0.39 \\
\hline \multirow{3}{*}{ Around gold mining zone } & Max & 1.32 \\
\hline & Min & 0.31 \\
\hline & Mean & 0.90 \\
\hline \multirow{3}{*}{ Recent Nile River terrace } & Max & 0.21 \\
\hline & Min & 0.10 \\
\hline & Mean & 0.16 \\
\hline \multirow{3}{*}{ Outside gold extraction basins } & Max & 1.52 \\
\hline & Min & 0.65 \\
\hline & Mean & 0.97 \\
\hline \multirow{3}{*}{ Inside gold extraction basins } & Max & 2.62 \\
\hline & Min & 1.02 \\
\hline & Mean & 1.82 \\
\hline
\end{tabular}

Comparing the mean of Hg concentrations in studied sites with the mean of Hg concentrations in world soils ( $0.09 \mathrm{mg} \mathrm{kg}^{-1}$ soil), all studied sites are above of $\mathrm{Hg}$ concentration in the world soils even in recent terrace site ( $0.16 \mathrm{mg} \mathrm{kg}^{-1}$ soil) it is near to couple times more. While comparing between Hg concentrations inside gold extraction basins at mining zone (1.82 $\mathrm{mg} \mathrm{kg}^{-1}$ soil) with the mean concentrations in world soils, it is more than 20 times more! That means that site must be closed and remediation process should be started immediately. However, the average concentration of total $\mathrm{Hg}$ in study area was lower than concentrations found in some gold mines around the world such as Almadén (Spain). Where Hg soil concentrations were 
found ranging between 0.13 and $2695 \mathrm{mg} \mathrm{kg}^{-1}$ (Molina et al., 2006); Idrija (Slovenia) and in alluvial soils range between 0.595 and $1970 \mathrm{mg} \mathrm{kg}^{-1}$ (Gosar and Žibret, 2011) or Wanshan (China) with total Hg contents in soils ranging between 5.1 and $790 \mathrm{mg} \mathrm{kg}^{-1}$ (Horvat et al., 2003). This may be attributed due to the fact the gold mining in the study area was started recently before 5 years ago.

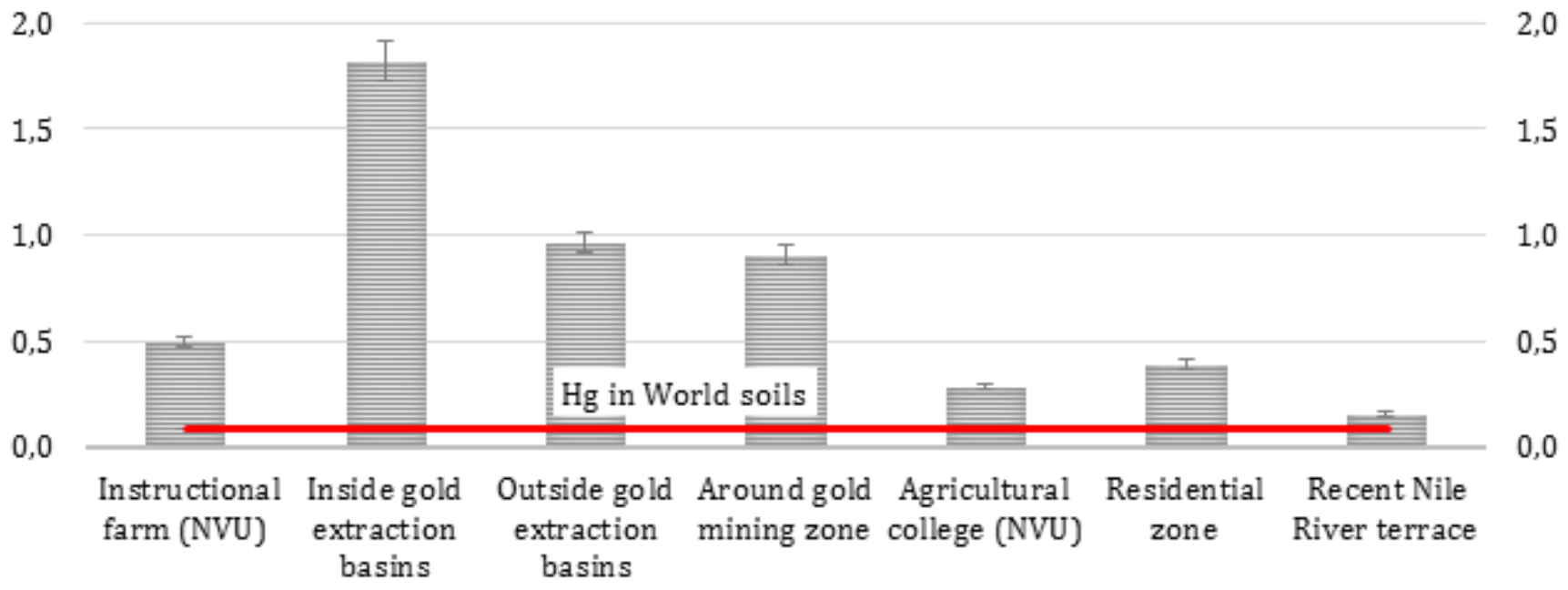

Figure 3. $\mathrm{Hg}$ concentrations ( $\mathrm{mg} \mathrm{kg}^{-1}$ ) in studied sites comparing with world soils

\section{Use of Enrichment factor (EF) to assess the Hg concentration in the study sites:}

According to Dragovic et al. (2008) classification, the EF value at studied sites were ranged from $8.7-352.8$ (Table 4), that means there is a significant contamination even at the recent Nile River terrace site (E.F 8.74) although, this area are renewed annually by transition and precipitation process from Nile River. The high contamination are classified in \%71 of studied sites, whereas the highest EF value are observed inside gold extraction basins (E.F 352.84).

Table 4. EF values in studied sites

\begin{tabular}{ll}
\hline Studied sites & EF \\
\hline Recent Nile River terrace & 8.740273 \\
Residential zone & 33.22241 \\
Agricultural college (NVU) & 23.63295 \\
Around gold mining zone & 83.44194 \\
Outside gold extraction basins & 107.1644 \\
Inside gold extraction basins & 352.8417 \\
Instructional farm (NVU) & 41.15672 \\
\hline
\end{tabular}

When distribution of $\mathrm{Hg}$ in studied sites was drawn using sigmaplot v12 software (Figure 4). We found that the distribution of $\mathrm{Hg}$ ranged from mining zone (highest concentration of $\mathrm{Hg}$ ) to southwest sites, this agreed by Ali et al. (2017) when studied the distributions of heavy metals in the same area, they interpreted that this was due to transition of pollutants via northeast wind, from mining zone to nearest areas at same wind direction.

On other hand, the distribution of $\mathrm{Hg}$ in our study looks like the distribution of the lead $(\mathrm{Pb})$ in Ali et al. (2017) study (Figure 5), where they studied the distribution of some heavy metals in the same area, this may be due to non-purity of $\mathrm{Hg}$ which used in gold extraction Figure 6, this hypothesis was supported by the ability of $\mathrm{Hg}$ to dissolve other metals like lead. This will be done by rubbing lead filings with $\mathrm{Hg}$ in a mortar or by pouring molten lead into Hg; this amalgam has no definite composition. It possesses a brilliant gray color and remains liquid with as much as $33 \%$ of lead and $67 \% \mathrm{Hg}$ although, lead is less dense than $\mathrm{Hg}$ (density of $\mathrm{Pb}$ is $11.340 \mathrm{~kg} / \mathrm{m}^{3}$ and density of $\mathrm{Hg}$ is $13.534 \mathrm{~kg} / \mathrm{m}^{3}$ ) (Mortazavi and Mortazavi, 2015). Finally, it was noticed that the appearance of $\mathrm{Hg}$ which using by miners it is seem mixed by other minerals, the one of it might be $\mathrm{Pb}$. 


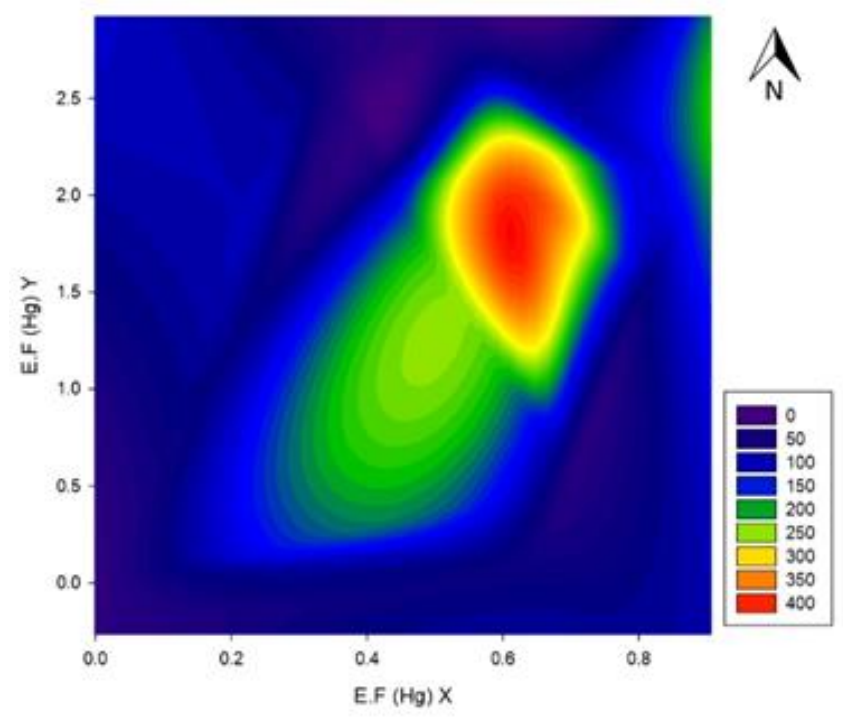

Figure 4. Hg distribution in studied area based on EF values (red color is the center of mining zone).

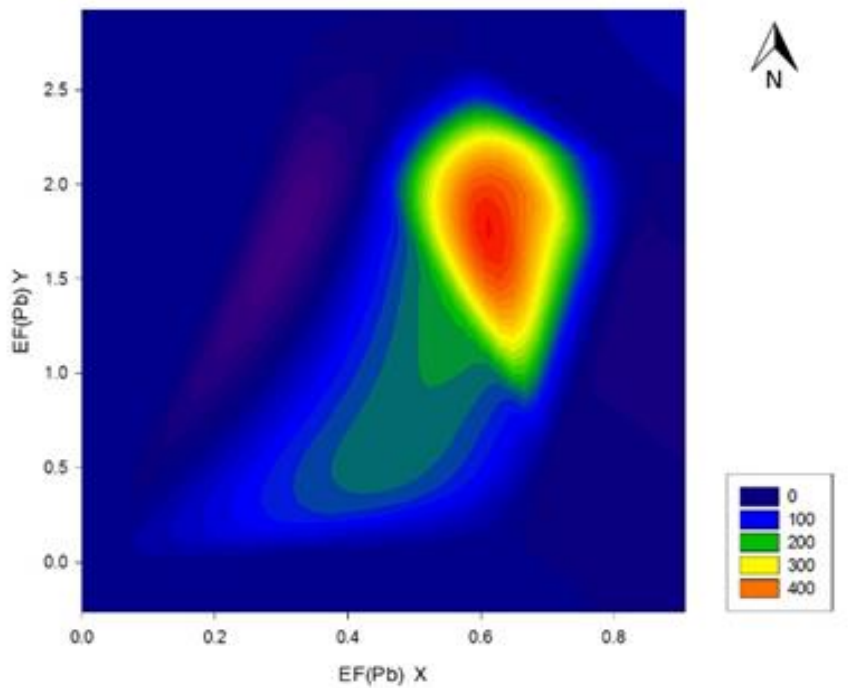

Figure 5. Distribution of $\mathrm{Pb}$ pollution in the study area based on EF values (red color is the center of mining area).

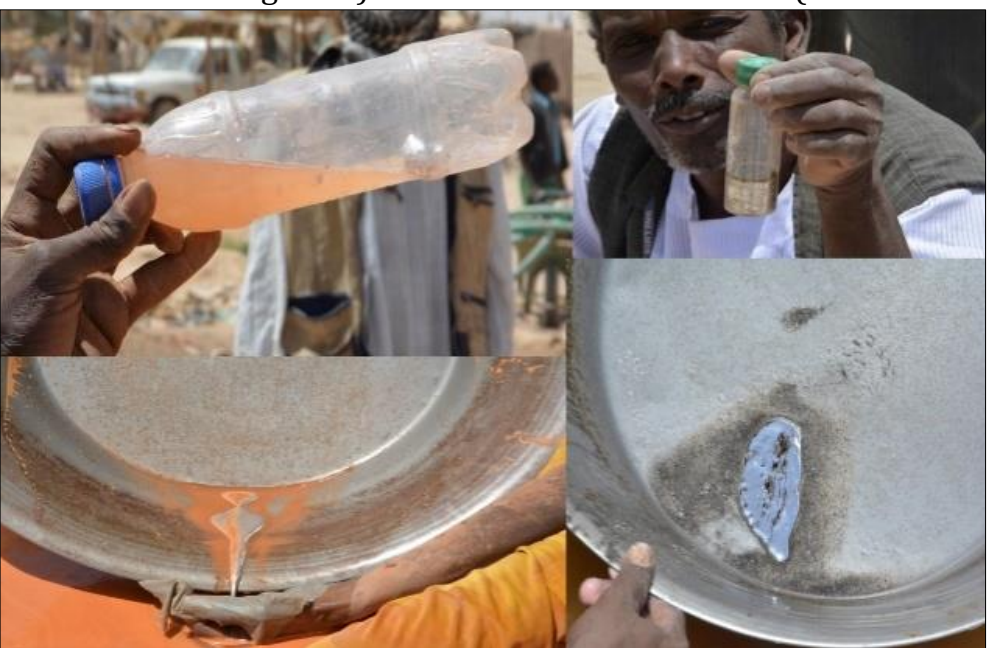

Figure 6. Utilization of $\mathrm{Hg}$ in gold extraction processes in the mining area.

\section{Conclusion}

After studied the mobility and distribution of $\mathrm{Hg}$ in soils around gold mining area at Dar-Mali Locality, River Nile State, it can be concluded that the $\mathrm{Hg}$ concentration in all sites are above the mean concentration of $\mathrm{Hg}$ in world soils. In addition, the distribution of $\mathrm{Hg}$ concentrations around the studied sites dispersed via northeast wind, from mining zone to nearest areas at same wind direction. Finally, the $\mathrm{Hg}$ concentrations inside gold extraction basins at mining zone $\left(1.82 \mathrm{mg} \mathrm{kg}^{-1}\right.$ soil) about 20 times more the mean $\mathrm{Hg}$ concentration in world soils! That means this site must be close and remediation possess should be stat immediately.

\section{References}

Ali, M., Elhagwa, A., Elfaki, J., Sulieman, M., 2017. Influence of the artisanal gold mining on soil contamination with heavy metals: A case study from Dar-Mali locality, North of Atbara, River Nile State, Sudan. Eurasian Journal of Soil Science 6(1): 28-36.

Cooke, J.A., Johnson, M.S., 2002. Ecological restoration of land with particular reference to the mining of metals and industrial minerals: a review of theory and practice. Environmental Reviews 10(1): 41-71.

Donkor, A.K., Bonzongo, J.J.C., Nartey, V.K., Adotey, D.K., 2005. Heavy metals in sediments of the gold mining impacted Pra River Basin, Ghana, West Africa. Soil and Sediment Contamination 14(6): 479-503.

Dragović, S., Mihailović, N., Gajić, B., 2008. Heavy metals in soils: Distribution, relationship with soil characteristics and radionuclides and multivariate assessment of contamination sources. Chemosphere 72(3): 491-495.

Elfaki, J.T., Gafer, M.A., Sulieman, M.M., Ali, M.E., 2016b. Hydrometer method against pipette method for estimating soil particle size distribution in some soil types selected from Central Sudan. International Journal of Engineering Research and Advanced Technology 2(2): 25-41. 
Elfaki, J.T., Gafer, M.O., Sulieman, M.M., Ali, M.E., 2016a. Assessment of calcimetric and titrimetric methods for calcium carbonate estimation of five soil types in central Sudan. Journal of Geoscience and Environment Protection 4(1): 120-127.

Elfaki, J.T., Sulieman, M.M., Nour, A.M., Ali, M.E., 2015. Short-term changes in inorganic nitrogen concentrations during storage at different temperatures of three different soils of the Nile River terraces, North of Sudan. Advances in Environmental Biology 9(24):397-402.

FA0, 2006. Guidelines for soil description, Fourth edition. Food and Agriculture Organization of the United Nations, Rome, Italy. Available at [access date: 14.12.2017]: http://www.fao.org/3/a-a0541e.pdf

Fernandes, A.B., Barros, F.L., Peçanha, F.M., Wiggers, G.A., Frizera, V.P., Ronacher, S.M., Stefanon, I., 2012. Toxic effects of mercury on the cardiovascular and central nervous systems. Journal of Biomedicine and Biotechnology Article ID 949048

Gosar, M., Žibret, G., 2011. Mercury contents in the vertical profiles through alluvial sediments as a reflection of mining in Idrija (Slovenia). Journal of Geochemical Exploration 110(2): 81-91.

Guedron, S., Grangeon, S., Lanson, B., Grimaldi, B., 2009. Mercury speciation in a tropical soil association; consequence of gold mining on Hg distribution in French Guyana. Geoderma 153(3-4): 331-346.

Horvat, M., Nolde, N., Fajon, V., Jereb, V., Logar, M., Lojen, S., Jacimovic, R., Falnago, I., Liya, Q., Faganeli, J., Drobne, D., 2003. Total mercury, methylmercury and selenium in mercury polluted areas in the province Guizhou, China. Science of The Total Environment 304 (1-3): 231-256.

Ledin, M., Pedersen, K., 1996. The environmental impact of mine wastes - Roles of microorganisms and their significance in treatment of mine wastes. Earth-Science Reviews 41(1-2): 67-108.

Link, D.D., Walter, P.J., Kingston, H.M., 1997. EPA Methods 3015A and 3051A: Validation studies for updated microwave leach methods. Waste Testing \& Quality Assurance Symposium (WTQA '97). July 6-9, 1997, Arlington, VA, USA. pp. 55-60.

Marx, E.S., Hart, J., Stevens, R.G., 1999. Soil test interpretation guide. Oregon State University Extension Service circular EC-1478. OR: Oregon State University. Corvallis, USA. Available at [access date: 14.12.2017]: http://ir.library.oregonstate.edu/xmlui/bitstream/handle/1957/14361/ec1478.pdf?sequence=3

Mason, R.P., Sheu, G., 2002. Role of the ocean in the global mercury cycle. Global Biogeochemical Cycles 16(4): 40-1-4014.

Molina, J.A., Oyarzun, R., Esbrí, J.M., Higueras, P., 2006. Mercury accumulation in soils and plants in the Almaden mining district, Spain: one of the most contaminated sites on Earth. Environmental Geochemistry and Health 28(5): 487498.

Mortazavi, G., Mortazavi. S.M.J., 2015. Increased mercury release from dental amalgam restorations after exposure to electromagnetic fields as a potential hazard for hypersensitive people and pregnant women. Reviews on Environmental Health 30(4): 287-292.

Olivero, J., Solano, B., 1998. Mercury in environmental samples from a waterbody contaminated by gold mining in Colombia, South America. Science of The Total Environment 217(1-2): 83-89.

Rhoades, J.D., 1996. Salinity: Electrical conductivity and total dissolved solids. In: Methods of Soil Analysis Part 3Chemical Methods. Sparks, D.L., Page, A.L., Helmke, P.A., Loeppert, R.H.(Eds.). SSSA Book Series 5.3. Soil Science Society of America, American Society of Agronomy, Madison, WI, USA. pp. 417-435.

Schuster, E., 1991. The behavior of mercury in the soil with special emphasis on complexation and adsorption processes - a review of the literature. Water Air \& Soil Pollution 56(1): 667-680.

Sinnott, R.W., 1984. Virtues of the Haversine. Sky and Telescope 68(2): 159.

Skyllberg, U., Bloom, P.R., Qian, J., Lin, C.M., Bleam, W.F., 2006. Complexation of Mercury(II) in soil organic matter: EXAFS evidence for linear two-coordination with reduced sulfur groups. Environmental Science and Technology 40(13): 4174-4180.

USDA, 2014a. Keys to Soil Taxonomy. United States Department of Agriculture, Natural Resources Conservation Service, Available at [access date: 14.12.2017]: https://www.nrcs.usda.gov/wps/PA_NRCSConsumption/download?cid=stelprdb1252094\&ext=pdf

USDA, 2014b. Kellogg Soil Survey Laboratory Methods Manual. Soil Survey Investigations Report No. 42, Version 5.0, United States Department of Agriculture, Natural Resources Conservation Service, National Soil Survey Center, Kellogg Soil Survey Laboratory, USA. Available at [access date: 14.12.2017]: https://www.nrcs.usda.gov/Internet/FSE_DOCUMENTS/stelprdb1253872.pdf

Wong, J.W.C., 1996. Heavy metal contents in vegetables and market garden soils in Hong Kong. Environmental Technology 17(4): 407-410.

Yin, R., Feng, X., Li, X., Yu, B., Du, B., 2014. Trends and advances in mercury stable isotopes as a geochemical tracer. Trends in Environmental Analytical Chemistry 2: 1-10. 